\title{
DOES Notarius bonillai (SILURIFORMES: ARIIDAE) OCCUR IN FRESHWATERS AND ESTUARINE IN ILHA DO MARANHÃO, BRAZIL?
}

\author{
Thiago Campos de Santana ${ }^{1 *}$, Jonatas da Silva Castro ${ }^{2}$, José Milton Barbosa ${ }^{3}$ \& Erivânia Gomes Teixeira ${ }^{4}$ \\ ${ }^{1}$ Pesquisador independente, Universidade Estadual do Maranhão, campus Paulo VI, Tirirical, 65055-970, São Luís, \\ Maranhão, Brasil. \\ ${ }^{2}$ Programa de Pós-Graduação em Aquicultura, Universidade Nilton Lins, 3259 Parque das Laranjeiras, Flores, \\ 69058-030, Manaus, Amazonas, Brasil \\ ${ }^{3}$ Departamento de Engenharia de Pesca e Aquicultura, Universidade Federal de Sergipe, Av. Marechal Rondon s/n, \\ Jardim Rosa Elze, 49100-000, São Cristovão, Sergipe, Brasil \\ ${ }^{4}$ Programa de Pós-Graduação em Recursos Aquáticos e Pesca, Universidade Estadual do Maranhão, campus Paulo \\ VI, Tirirical, 65055-970, São Luís, Maranhão, Brasil \\ *Autor correspondente: thsantana21@hotmail.com
}

\begin{abstract}
This paper deals with the occurrence of the species Notarius bonillai (Miles, 1945) in waters of Ilha do Maranhão (or Ilha de São Luís), Maranhão, Brazil. The investigation is necessary to clarify the distribution of this species before any regional study on it can be made. In seven previous studies, Notarius bonillai is mentioned as living in waters of this region: in São José Bay in the east, São Marcos Bay in the west, and Arraial bay in the south. However, several studies in South America report the species as endemic of the two rivers and their estuaries, which flow into the coast of the Caribbean Sea of Colombia. Analysis included preserved specimens identified as Notarius bonillai from a regional fish collection of Ilha do Maranhão. Additional material of Cathorops specimens were collected in the municipality of Raposa, located near estuary of rio Paciência in the east of Ilha do Maranhão. Analysis of the morphological characteristics of preserved specimens of the regional fish collection, indicate that the species identified as Notarius bonillai in the region was erroneously identified, instead being Cathorops arenatus (Valenciennes, 1840). Morphological analysis of the additional material collected from Cathorops specimens indicate three species of Cathorops occurring in Ilha do Maranhão: Cathorops agassizii (Eigenmann \& Eigenmann, 1888), Cathorops arenatus (Valenciennes, 1840), and Cathorops spixii (Agassiz, 1829). Consequently, Notarius bonillai does not occur in Ilha do Maranhão.
\end{abstract}

Key words: Estuaries, Nueva Granada sea catfish, bagre cabezón, uriacica, São Marcos Bay, São José Bay.

\section{RESUMO}

Este trabalho trata da ocorrência da espécie Notarius bonillai (Miles, 1945) na Ilha do Maranhão (ou Ilha de São Luís), Maranhão, Brasil. A investigação é necessária para esclarecer a distribuição desta espécie antes que qualquer estudo regional sobre ela possa ser feito. Em sete estudos anteriores, Notarius bonillai é mencionado como vivendo nas águas desta região: na Baía de São José a leste, na Baía de São Marcos a oeste e na Baía de Arraial ao sul. No entanto, vários estudos na América do Sul relatam a espécie como endêmica de dois rios e seus estuários, que desembocam na costa do Mar do Caribe na Colômbia. Análises incluíram espécimes preservados como Notarius bonillai de uma coleção regional de peixes da Ilha do Maranhão. Material adicional de espécimes de Cathorops foram coletados no município de Raposa, localizado próximo ao estuário do rio Paciência, no leste da Ilha do Maranhão. A análise dos caracteres morfológicos dos espécimes preservados na coleção regional de peixes, indicam que a espécie identificada como Notarius bonillai na região foi erroneamente identificada, sendo Cathorops arenatus (Valenciennes, 1840) sua correta identificação. Análises morfológicas do material adicional de espécimes de Cathorops coletados indicam três espécies de Cathorops com ocorrência na Ilha do Maranhão: Cathorops agassizii (Eigenmann \& Eigenmann, 1888), Cathorops arenatus (Valenciennes, 1840) e Cathorops spixii (Agassiz, 1829). Consequentemente, Notarius bonillai não ocorre na Ilha do Maranhão.

Palavras-chave: Estuários, Nueva Granada sea catfish, bagre cabezón, uriacica, Baía de São Marcos, Baía de São José. 


\section{INTRODUCTION}

In recent studies (Aguiar-Santos et al. 2018, Silva et al. 2018), it was reported the occurrence of Notarius bonillai (Miles, 1945) in São Marcos Bay, an estuarine complex located at east of the Ilha do Maranhão, northeastern Brazil. In previous studies Soares et al. (2011) and Silva Júnior et al. (2013) reported this species in the estuary of the rio Paciência, at east, and Castro et al. (2010) reported in the area south of the Ilha do Maranhão. However, several studies in South America report the species as endemic to the two rivers and their estuaries, which flow into the coast of the Caribbean Sea of Colombia (Dahl 1971, Marceniuk \& Ferraris 2003, Ferraris 2007, Acero \& Betancur-R 2006, Acero 2012, Montoya-López et al. 2013).

Notarius bonillai is an ariid catfish that inhabit fresh and estuarine habitats (Acero 2012). It was originally described by Miles (1945) as Galeichthys bonillai, based on a specimen captured in Honda (Colombia), and apparently its neotype was lost (Mojica \& Agudelo-Zamora 2018). According to Acero \& Betancur-R (2006), Acero et al. (2017) and Marceniuk et al. (2017), in studies carried out in the Caribbean region, the Nueva Granada sea catfish was erroneously recognized during the late twentieth century, in other ariid genera: Ariopsis bonillai (e.g., Taylor \& Menezes 1978, Galvis 1984, Cervigón et al. 1992, Acero 2003, Ferraris 2007), Arius bonillai (Burgess 1989, Acero 1996), Hexanematichthys bonillai (Marceniuk \& Ferraris 2003) or Sciades bonillai (Marceniuk \& Menezes 2007).

Marceniuk et al. (2017) reviewed the species of the genus Ariopsis and described two new species. One of them is the species Ariopsis canteri, a catfish of the Caribbean region (coast of Colombia in Western Atlantic), occurring in marine and brackish waters and it rarely enters freshwaters. These authors further states that $A$. canteri is the valid name of the endemic catfish commonly known as "Nueva Granada sea catfish", "bagre cazón" or "chivo cabezón" and is currently listed as endangered (Acero et al. 2017). Notarius bonillai, commonly known in the Caribbean region as "bagre de río" or "bagre blanco" is a ariid catfish restricted to Madalena and Atrato rivers basins, draining to the Colombian Caribbean (Acero \& Betancur-R 2006, Acero 2012). Considering the importance of the taxonomic description of the species for the region, the aim of this study was to evaluate the occurrence of Notarius bonillai in fresh and estuarine waters of Ilha do Maranhão (or Ilha de São Luís), Maranhão, Brazil, based on the analysis of the morphological characters of the specimens collected and deposited in a regional fish collection, with the hypothesis that the records for this region are imprecise.

\section{MATERIALS AND METHODS}

In the laboratory the species were identified using the descriptions and identification keys proposed by Acero (2003), Marceniuk (2007) and Marceniuk et al. (2012). Analysis included specimens preserved in the Fish Collection of the Federal University of Maranhão (Coleção de Peixes da Universidade Federal do Maranhão-CPUFMA). Additional material included specimens collected between July and August 2018 at the fishing terminal in the municipality of Raposa $\left(2^{\circ} 25^{\prime} 1\right.$ 's, $\left.44^{\circ} 6^{\prime} 21^{\prime \prime} \mathrm{W}\right)$, located in East of Ilha do Maranhão. The morphological characters of the species Notarius bonillai and Ariopsis canteri, were compared with Cathorops species analized using the descriptions proposed by Miles (1945), Acero \& Betancur-R (2006) and Marceniuk et al. (2017). After analyzing the morphological characters, tissue samples of the specimens collected were deposited in the Collection of Tissues and DNA from Maranhão Fauna (Coleção de Tecidos e DNA da Fauna MaranhenseCoFauMA), State University of Maranhão (UEMA). All specimens analyzed were measured (total length, Lt or standard length, Ls) in millimeters (mm).

\section{RESULTS AND DISCUSSION}

Field collections where conducted near the estuary of the rio Paciência in the east of Ilha do Maranhão, through conversations with local fishermen, the specimens were collected based on the popular name "uriacica", because it's mentioned in the bibliographies of the region for the species Notarius bonillai (Barbosa \& Nascimento 2009, SEMA 2010). A total of twenty specimens were collected from the field.

Based on observations and analysis of the morphological characters of five specimens deposited in the CPUFMA as Notarius bonillai, we verified they were erroneously identified, and were instead Cathorops arenatus (Valenciennes, 1840).

Twenty-five specimens were analyzed, representing a total of three species: Cathorops spixii (Agassiz, 1829), Cathorops agassizii (Eigenmann \& Eigenmann, 1888) and Cathorops arenatus (Valenciennes, 1840). Our results are based on the comparison of Cathorops arenatus with the other Cathorops species present in Ilha do Maranhão (C. agassizii and C. spixii), and N. bonillai and A. 
canteri, endemic catfishes from the Caribbean region of Colombia.

\section{Catalog of species:}

In this section "material deposited" indicates specimens collected in field in the present study and "material examined" indicates specimens analyzed during our visit to CPUFMA. The diagnosis of species where based on the descriptions and diagnosis of the papers of Miles (1945), Acero \& Betancur-R (2006), Marceniuk (2007), Marceniuk et al. (2012) and Marceniuk et al. (2017).

\section{Cathorops spixii (Agassiz, 1829) (Fig. 1a)}

English name: madamango sea catfish; Portuguese name: uriacica-amarelo; Spanish name: bagre cuinche

Material deposited: CoFauMA CMICs 01 (2, Ls 90-154 mm), Brazil, Maranhão: Ilha do
Maranhão, Raposa, Fish Market, 31 Jul. 2018. CoFauMA CMICs02 (7, Ls 138-172 mm), Brazil, Maranhão: Ilha do Maranhão, Raposa, Fish Market, 30 Aug. 2018. CoFauMA CMICs03 (4, Ls 136-175 $\mathrm{mm})$, Brazil, Maranhão: Ilha do Maranhão, Raposa, Fish Market, 31 Aug. 2018.

Cathorops agassizii (Eigenmann \& Eigenmann, 1888) (Fig. 1b)

English name: gaviota sea catfish; Portuguese name: uriacica-branco; Spanish name: bagre cuinche de río

Material deposited: CoFauMA CMICag01 (1, Ls 125 mm), Brazil, Maranhão: Ilha do Maranhão, Raposa, Fish Market, 31 Jul. 2018.

Cathorops arenatus (Valenciennes, 1840) (Fig. 1c) English name: yellow sea catfish; Portuguese name: uriacica-amarelo, Spanish name: bagre cuinche amarillo

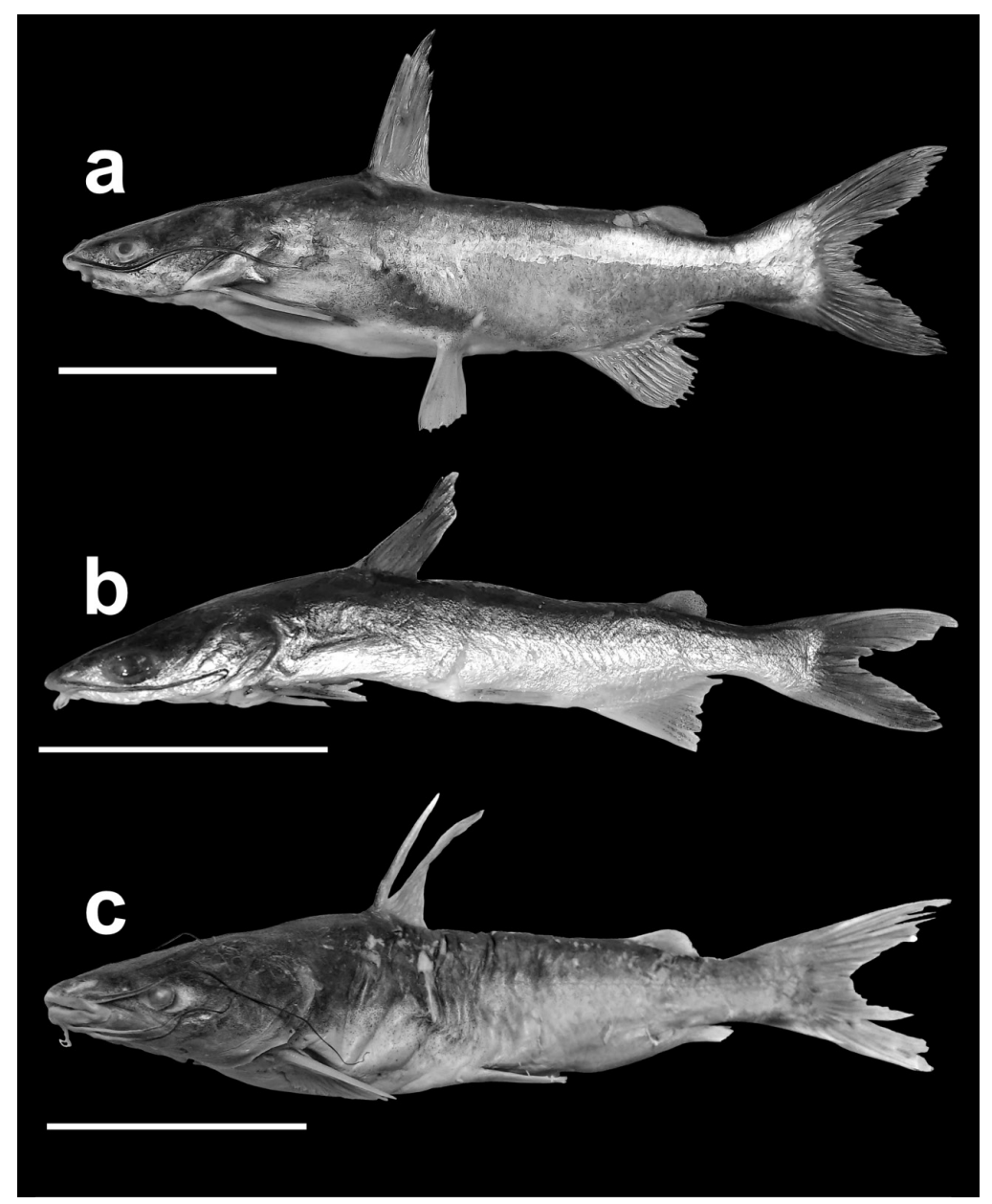

Figure 1. Body in lateral view of Cathorops species. (a) Cathorops spixii, $204 \mathrm{~mm}$ Lt; (b) Cathorops agassizii $158 \mathrm{~mm} \mathrm{Lt}$; (c) Cathorops arenatus, CPUFMA 11871 , $175 \mathrm{~mm}$ Lt. Scale bars $=50 \mathrm{~mm}$. 
Material deposited: CoFauMA CMICar01 (3, Ls 127-179 mm), Brazil, Maranhão: Ilha do Maranhão, Raposa, Fish Market, 31 Jul. 2018. CoFauMA CMICar02 (3, Ls 119-174 mm), Brazil, Maranhão: Ilha do Maranhão, Raposa, Fish Market, 30 Aug. 2018.

Material examined: The following 5 specimens examined were labeled as Notarius bonillai, all were reidentified as Cathorops arenatus: CPUFMA 11871 (5, Ls 121.67-143.64 mm), Brazil, Maranhão: São Luís, Baía de São Marcos, Igarapé Buenos Aires/Cabeceira, Oct. 2011.

Diagnosis of species: Comparing the species Cathorops arenatus and Cathorops agassizii, the former differs from the latter, since $C$. arenatus presents long maxillary barbels, exceeding of the pectoral fin bases, while C. agassizii has short maxillary barbels, hardly reaching the pectoral-fin bases. The species can also be further differentiated from $C$. agassizii as follows: lips thick, with the lower lip thicker than the upper lip (vs. lips relatively thick, with the upper lip thicker than lower lip); eyes small, 3.1-4.5\% of Ls (vs. eyes large, $4.7-7.1 \%$ of Ls). Cathorops arenatus can be differentiated from Cathorops spixii by having 39-40 free vertebrae (vs. 41-42), and orbital diameter 4.2-6.0 (rarely 4.1) in width of cephalic shield in the supracleithrum area (vs. 2.8-4.1). Compared to the species Cathorops spixii and $C$. agassizii, the species $C$. arenatus differs from the other two because is the dorsomedial groove of the neurocranium short and narrow on median portion (vs. long dorsomedial groove, and broader in the median portion) (Fig. 2a-c). Finally, when Cathorops spp. is compared to the species Ariposis canteri and Notarius bonillai, the former differs mainly because it has only the accessory tooth plates in the palate region, and it does not have vomerine tooth plates (Fig. 3a-c), while the two others have both accessory and vomerine tooth plates.

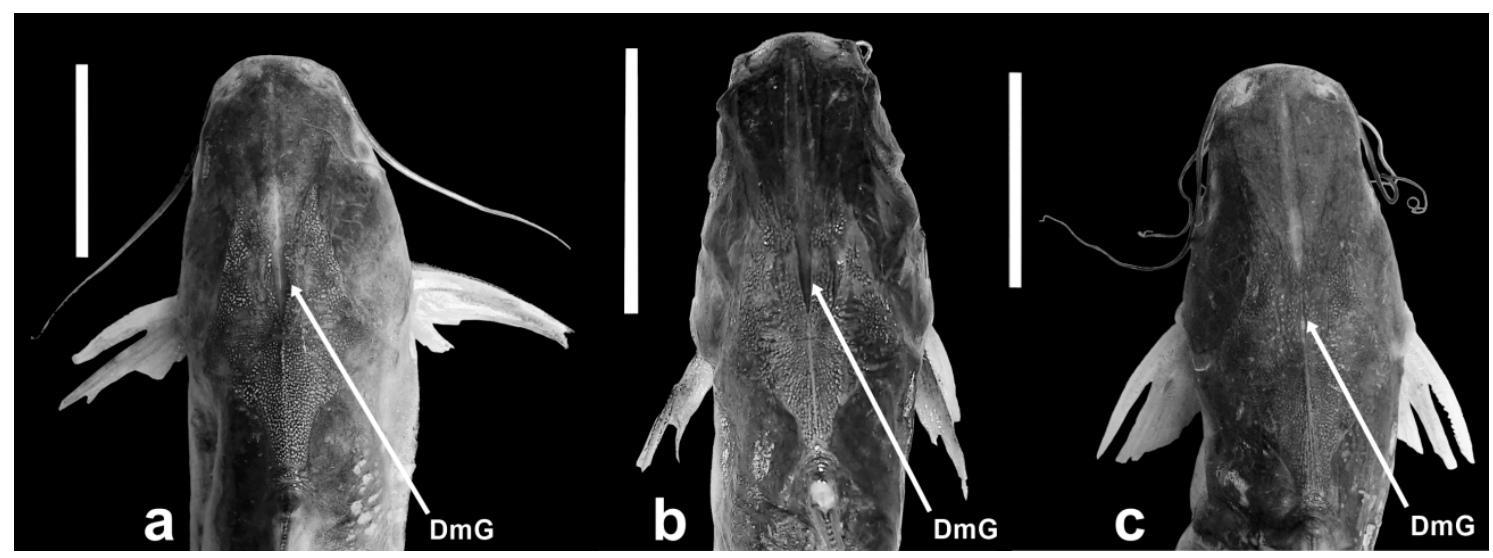

Figure 2. Dorsal view of the head showing the dorsomedial groove between the frontals area in the cephalic shield. (a) Cathorops spixii, $204 \mathrm{~mm} \mathrm{Lt}$ (b) Cathorops agassizii, $158 \mathrm{~mm} \mathrm{Lt}$; (c) Cathorops arenatus, CPUFMA 11871, 175 mm Lt. Abbreviation: $\mathrm{DmG}=$ dorsomedial groove. Scale bars $=30 \mathrm{~mm}$.

a

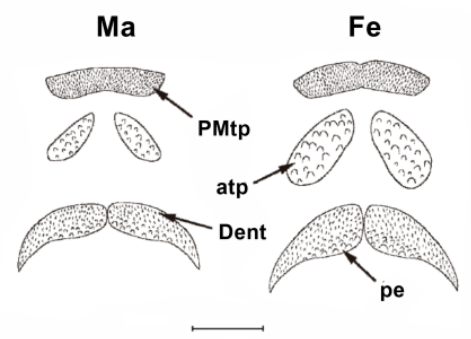

b

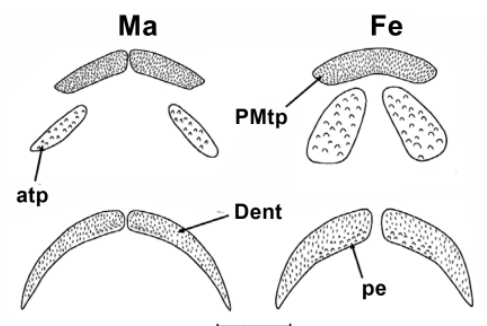

C

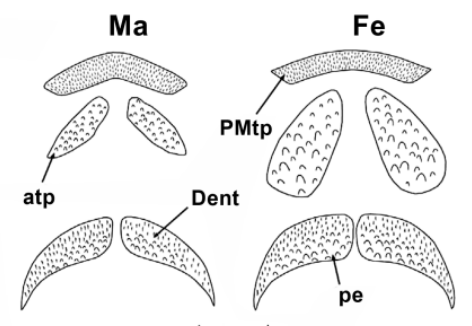

Figure 3. Illustrations of tooth plates of Cathorops species. (a) Cathorops spixii; (b) Cathorops agassizii; (c) Cathorops arenatus. Abbreviations: $\mathrm{Ma}=$ male; $\mathrm{Fe}=$ female, atp = accessory tooth plates; Den = dentary; pe = posterior expansion PMtp $=$ premaxillary tooth plate. Scale bars $=2 \mathrm{~mm}$. Fig. 3a: adapted from Marcenniuk et al. (2012, p. 83). Fig. 3b-c: adapted from Marceniuk (2007, p. 367 and 372). 
Notarius bonillai have been reported erroneously in several studies related to the fish fauna of fresh and estuarine waters in the Ilha do Maranhão, northeastern Brazil, being cited as Hexanematichthys bonillai (e.g., Silva Júnior et al. 2007, SEMA 2010, Silva et al. 2018), Arius bonillai (Castro et al. 2010), Ariopsis bonillai (Soares et al. 2011, Silva Júnior et al. 2013) or Notarius bonillai (Aguiar-Santos et al. 2018). Notarius bonillai has also been reported in the state of Sergipe (Araújo et al. 2017), and in fishing production data of fish captured in the Brazilian territory (MPA 2009, 2010, 2011). However, we did not analyze samples collected in other Brazilian states.
In study related to the fish fauna of Ilha do Maranhão, organized by the Secretary of State for the Environment and Water Resources (Secretaria de Estado do Meio Ambiente e Recursos NaturaisSEMA) (SEMA 2010), Notarius bonillai was reported for estuaries of the rio Anil and rio Paciência. When checking the photographic guide of SEMA (2010), we verified that Cathorops arenatus was erroneously reported as Notarius bonillai (Fig. 4), with popular name of "uriacica". In addition, the popular name "uriacica" is used in the north and northeastern of Brazil for species of Cathorops Jordan \& Gilbert, 1883 (Martin-Juras et al. 1987, Freire \& Pauly 2005, Silva \& Silva 2012).

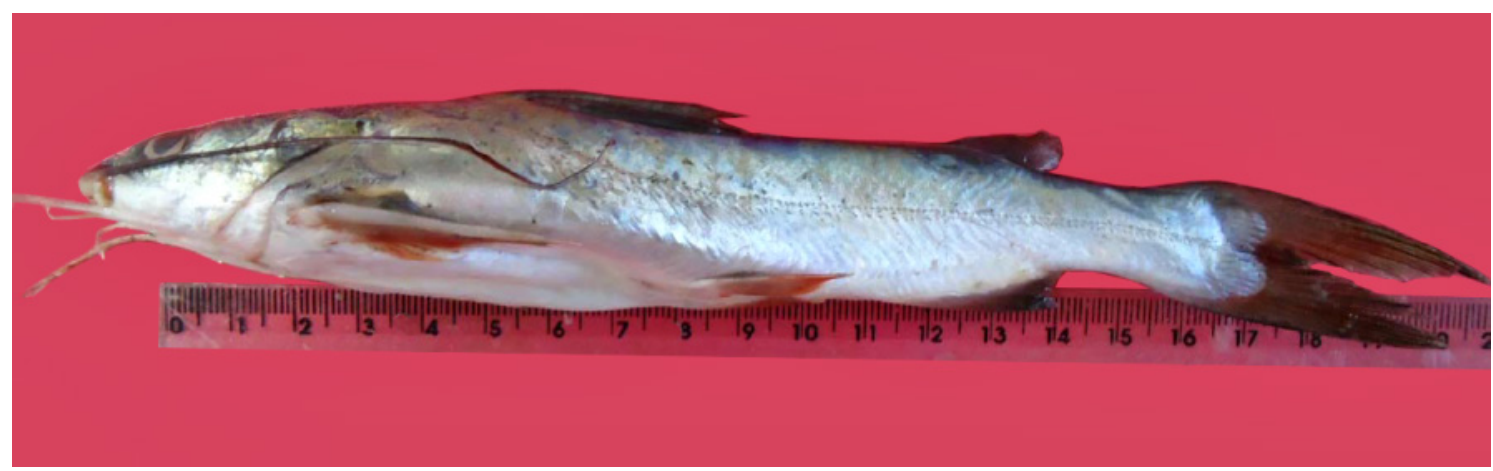

Figure 4. Cathorops arenatus, erroneously reported as Notarius bonillai. Figure adapted from SEMA (2010, p. 409).

The correct identification of the species of Cathorops becomes relevant due to the great abundance and ecological importance of these species in the coastal, estuarine and freshwater environments where they occur (Etchevers 1978, Mishima \& Tanji 1981, Lara-Domínguez et al. 1982, Castro 2001, Barletta et al. 2003, Lasso et al. 2004a,b, Marceniuk 2007, Ayala-Pérez et al. 2008, Acero 2011). In the state of Maranhão Cathorops species are among the main fishery resources, mainly in coastal communities, being caught during the whole year (Almeida 2009).

As there is no evidence of the presence of Notarius bonillai in Brazil (with specimens in collections), and according to taxonomic comparisons performed in this study, we suggest a nomenclature update in fish identified as Notarius bonillai, which is an endemic catfish of the two rivers and their estuaries, which flow into the coast of the Caribbean Sea of Colombia. Therefore, fish identified as Notarius bonillai in the study area, based on morphological characters, should be cited as Cathorops arenatus (Valenciennes, 1840), in the Ilha do Maranhão, Maranhão, Brazil.

\section{Acknowledgements}

Thank you to the Laboratório de Ecologia e Sistemática de Peixes (LABESP), of the Federal University of Maranhão-UFMA, especially to Professor Dr. Nivaldo Magalhães Piorski and Ananda Carolina Serejo Saraiva, who kindly allawed us to analyze the fishes deposited in the Fish Collection of the Federal University of Maranhão (Coleção de Peixes da Universidade Federal do Maranhão-CPUFMA).

\section{STATEMENT ON THE WELFARE OF ANI- MALS}

All applicable international, national, and/ or institutional guidelines for the care and use of animals were followed. All procedures performed in studies involving animals were in accordance with the ethical standards from the Chico Mendes Institute for Biodiversity and Conservation (Instituto Chico Mendes de Conservação da Biodiversidade, ICMBio; license number 64161-1). 


\section{REFERENCES}

ACERO, P.A. 1996. Arius bonillai. The IUCN Red List of Threatened Species 1996. Accessible at http:// www.iucnredlist.org/details/190224/0 (accessed 09/12/2018).

ACERO P.A. 2003. Ariidae. Pp. 831-852. In: Carpenter, K.E. (ed). The living marine resources of the Western Central Atlantic Vol. 2. Rome: Food and Agriculture Organization of the United Nations.

ACERO, P.A. \& BETANCUR-R, R. 2006. Real identity of the northern Colombian endemic sea catfish Galeichthys bonillai Miles, 1945 (Siluriformes: Ariidae). Cybium 30: 215-219.

ACERO, P.A. 2011. Bagre cuiche: Cathorops sp. Pp.164-165. In: Lasso, C. \& Sánchez-Duarte, P. Los peces del Delta de Orinoco: diversidad, bioecología, uso y conservación. Fundación La Salle de Ciencias Naturales y Chevron C.A. Venezuela. Caracas. $500 \mathrm{p}$.

ACERO, P.A. 2012. Notarius bonillai. Pp. 6566. In: Mojica, J.I., Usma, J.S., Álvarez-León, R. \& Lasso, C.A. (eds). Libro rojo de peces dulceacuícolas de Colombia 2012. Instituto de Investigación de Recursos Biológicos Alexander von Humboldt, Instituto de Ciencias Naturales de la Universidad Nacional de Colombia, WWF Colombia y Universidad de Manizales Bogotá, D. C., Colombia, 319 p.

ACERO, P.A., POLANCO, A. \& ALMANZA, M. 2017. Ariopsis sp. Pp. 73-76. In: Chasqui-Velasco L., Polanco, A., Acero, P.A., Mejía-Falla, P.A., Navia, A., Zapata, L.A. \& Caldas, J.P. (eds). Libro rojo de peces marinos de Colombia 2017. Santa Marta: INVEMAR.

AGASSIZ, L. 1829. In: Spix, J.B. von \& Agassiz, L. 1829. Selecta genera et species piscium quos in itinere per Brasiliam annos 1817-1820 jussu et auspiciis Maximiliani Josephi I. Selecta genera et species piscium brasiliensium, $138 \mathrm{p}$. Monachii [München]: Typis C. Wolf,1829-[31].

AGUIAR-SANTOS, J., SAMPAIO, A.S., BARROSO, T.L., NUNES, J.L. \& PIORSKI, N.M. 2018. Length-weight relationships of six fish species from São Marcos Bay, Northeastern Brazil. J. Appl. Ichthyol., 34(4): 1084-1086.

ALMEIDA, Z.S. 2009. Os recursos pesqueiros marinhos e estuarinos do Maranhão: biologia, tecnologia, socioeconomia, estado da arte e manejo. Tese de Doutorado. Universidade Estadual do Pará, Belém, 283 p.
ARAÚJO, A.R.R., SOUZA, J.M., LIMA, R.C.D., ABREU, E.F.S., VIRGENS, F.F. \& BARBOSA, J.M. 2017. Diversidade da fauna aquática do estuário do rio Japaratuba, estado de Sergipe, Brasil. Acta Fish., 5(1): 33-42.

AYALA-PÉREZ, L.A., RAMOS-MIRANDA, J., FLORES-HERNÁNDEZ, D., VEGARODRÍGUEZ, B.I. \& MORENO-MEDINA, U.C. 2008. Caracterización biológica y ecológica del bagre Cathorops melanopus de la costa oeste de Campeche, México. Cienc. Mar., 34(4): 453-465.

BARBOSA, J.M. \& NASCIMENTO, C. 2009. Sistematização de nomes vulgares de peixes comerciais do Brasil: 2. Espécies marinhas. Rev. Bras. Eng. Pesca, 3(3): 77-91.

BARLETTA M., BARLETTA-BERGAN, A., SAINT-PAUL, U. \& HUBOLD, G. 2003. Seasonal changes in density, biomass, and diversity of estuarine fishes in tidal mangrove creeks of the lower Caeté Estuary (northern Brazilian coast, east Amazon). Mar. Ecol. Prog. Ser., 256: 217-228.

BURGESS, W.E. 1989. An atlas of freshwater and marine catfishes: A preliminary survey of the Siluriformes, 784 pp. New Jersey: T.F.H. Publications.

CASTRO, A.C.L. 2001. Diversidade da assembleia de peixes em igarapés do estuário do Rio Paciência (MA-Brasil). Atlântica, 23: 39-46.

CASTRO, A.C.L., CASTRO, K.D.D. \& PORTO, H.L.R. 2010. Distribuição da assembléia de peixes na área de influência de uma indústria de alumínio na Ilha de São Luis-MA. Arq. Cienc. Mar., 43(2): 71-78.

CERVIGÓN F., CIPRIANI, R., FISCHER, W., GARIBALDI, L., HENDRICKX, M., LEMUS, A.J., MÁRQUEZ, R., POUTIERS, M., ROIJAINA, G. \& RODRIGUEZ, B. 1992. Guía de campo de las especies comerciales marinas y de aguas salobres de la Costa Septentrional de Sur América. Rome: Food and Agriculture Organization of the United Nations. 513 p.

DAHL, G. 1971. Los peces del norte de Colombia, 391 pp. Bogotá: INDERENA.

EIGENMANN, C.H. \& EIGENMANN, R.S. 1888. Preliminary notes on South American Nematognathi, I. Proc. Calif. Acad. Sci., 1: 119-172.

ETCHEVERS, S.L. 1978. Contribution to the biology of the sea catfish, Arius spixii (Agassiz) 
(Pisces-Ariidae) south of Margarita Island, Venezuela. B. Mar. Sci., 28(2): 381-385.

FERRARIS, C.J. 2007. Checklist of catfishes, recent and fossil (Osteichthyes: Siluriformes), and catalogue of siluriform primary types. Zootaxa, 1418:1-300.

FREIRE, K.M. \& PAULY, D. 2005. Richness of common names of Brazilian marine fishes and its effect on catch statistics. J. Ethnobiol., 25(2): 279-297.

GALVIS, O. 1984. Estimación del crecimiento y mortalidad del chivo cabezón Ariopsis bonillai (Miles, 1945) (Pisces: Siluriformes: Ariidae) en la Ciénaga Grande de Santa Marta. An. Inst. Invest. Mar. Punta Betín, 14: 67-84.

LARA-DOMÍNGUEZ A.L., YÁÑEZARANCIBIA, A. \& AMEZCUA-LINARES, F. 1981. Biología y ecología del bagre Arius melanopus (Günther) en la Laguna de Términos, sur del Golfo de México (Pisces: Ariidae). An. Inst. Cienc. Mar. Limnol. Univ. Nac. Auton. Mex., 8: 267-304.

LASSO, C., LASSO-ALCALÁ, O., POMBO, C.\& SMITH, M. 2004a. Ictiofauna de las aguas estuarinas del delta del río Orinoco (caños Pedernales, Manamo, Manamito) y golfo de Paria (río Guanipa): Diversidad, distribución, amenazas y criterios para su conservación. Pp. 70-84. In: Lasso, C., Alonso, L., Love, G. \& Flores, A. (eds.). A Biological Assessment and Socio Economical Aspects of the Aquatic Ecosystems of the Gulf of Paria and Orinoco Delta. RAP Bulletin of Biological Assessment $N^{\circ} 37$. Conservation International, Washington, D.C., USA.

LASSO, C., LASSO-ALCALÁ, O., POMBO, C. \& SMITH, M. 2004b. Composición, abundancia y biomasa de la ictiofauna béntica del delta del río Orinoco (caño y boca de Pedernales, Manamo, Manamito, boca de Bagre) y golfo de Paria (río Guanipa, caño Venado), Venezuela. Pp. 85-102. In: Lasso, C., Alonso, L., Love, G. \& Flores, A. (eds.). A Biological Assessment and Socio Economical Aspects of the Aquatic Ecosystems of the Gulf of Paria and Orinoco Delta, Venezuela. RAP Bulletin of Biological Assessment $\mathrm{N}^{\circ}$ 37. Conservation International, Washington, D.C., USA.

MARCENIUK, A.P. \& FERRARIS, C.J. 2003. Family Ariidae (Sea catfishes). Pp. 447-455. In: Reis, R.E., Kullander, S.O. \& Ferraris, C.J. (eds). Check list of the freshwater fishes of South and Central America. Porto Alegre: EDIPUCRS.

MARCENIUK,A.P. 2007. Revalidação de Cathorops arenatus e Cathorops agassizii (Siluriformes, Ariidae), bagres marinhos das regiões norte e nordeste da América do Sul. Iheringia Ser. Zool., 97(4): 360-375.

MARCENIUK, A.P. \& MENEZES, N.A. 2007. Systematics of the family Ariidae (Ostariophysi, Siluriformes), with a redefinition of the genera. Zootaxa, 1416: 1-126.

MARCENIUK, A.P., BETANCUR-R, R. \& MURIEL-CUNHA, J. 2012. Review of the genus Cathorops (Siluriformes: Ariidae) from the Caribbean and Atlantic South America, with description of a new species. Copeia, 2012: 77-97.

MARCENIUK, A.P., ACERO, P.A., COOKE R. \& BETANCUR-R, R. 2017. Taxonomic revision of the New World genus Ariopsis Gill (Siluriformes: Ariidae), with description of two new species. Zootaxa, 4290: 1-42.

MARTINS-JURAS, I.D.A.G., JURAS, A.A., \& MENEZES, N.A. 1987. Relação preliminar dos peixes da ilha de São Luís, Maranhão, Brasil. Rev. Bras. Zool., 4(2): 105-113.

MILES, C. 1945. Some newly recorded fishes from the Magdalena River system. Caldasia, 3(15): 453464.

MISHIMA, M. \& TANJI, S. 1981. Distribuição geográfica dos bagres marinhos (Osteichthyes, Ariidae) no complexo estuarino lagunar de Cananéia $\left(25^{\circ} \mathrm{S}, 48^{\circ} \mathrm{W}\right)$. Bol. Inst. Pesca., 8: 157-172.

MOJICA, J.I. \& AGUDELO-ZAMORA, H.D. 2018. Historical review, catalog of type specimens and online database of the ichthyology collection of the Instituto de Ciencias Naturales of the Universidad Nacional de Colombia (ICNMHN). Zootaxa, 4478(1): 1-79.

MONTOYA-LÓPEZ, A.F., OSPINA-PABÓN, J.G. \& AGUDELO-ZAMORA, H.D. 2013. Los Peces del Departamento de Antioquia (Colombia). Bol. Cient. Mus. Hist. Nat., 17 (2): 95 - 109.

MPA - Ministério da Pesca e Aquicultura. 2009. Boletim Estatístico da Pesca e Aquicultura 2008-2009, 99 pp. Brasília: MPA. Accessible at http://www.icmbio.gov.br/cepsul/images/stories/ biblioteca/download/estatistica/est_2008_2009_nac_ pesca.pdf (accessed 09/21/2018).

MPA - Ministério da Pesca e Aquicultura. 2010. Boletim Estatístico da Pesca e Aquicultura 2010, 129 pp. Brasília: MPA. Accessible at http://www.icmbio. gov.br/cepsul/images/stories/biblioteca/download/ estatistica/est_2010_nac_boletim.pdf (accessed 09/21/2018). 
MPA - Ministério da Pesca e Aquicultura. 2011. Boletim Estatístico da Pesca e Aquicultura 2011, 60 pp. Brasília: MPA. Accessible at http://www.icmbio. gov.br/cepsul/images/stories/biblioteca/download/ estatistica/est_2011_bol_bra.pdf (accessed 09/21/2018).

SEMA - Secretaria de Estado do Meio Ambiente e Recursos Naturais. 2010. Diagnóstico ambiental da ilha do maranhão - Com a implementação do programa estadual de gerenciamento costeiro do estado do Maranhão - Gerco ilha do Maranhão - etapa 1. Accessible at https://docplayer.com. br/56067310-Governo-do-estado-do-maranhaosecretaria-do-meio-ambiente-e-recursos-naturaissema-ma.html (accessed 04/28/2019).

SILVA, A.S. \& SILVA, T.F. 2012. A Influência Tupí nos Nomes de Peixes do Litoral Bragantino. A Palavrada, 1(1): 10-28.

SILVA, M.H.L., TORRES JÚNIOR, A.R., CASTRO, A.C.L., AZEVEDO, J.W.J., FERREIRA, C.F.C., CARDOSO, R.L., NUNES, J.L.S. \& CARVALHO-NETA, R.N.F. 2018. Fish assemblage structure in a port region of the Amazonic coast. Iheringia Ser. Zool., 108.
SILVA JÚNIOR, M.G., CASTRO, A.C.L., SOARES, L.S. \& FRANÇA, V.L. 2007. Relação peso-comprimento de espécies de peixes do estuário do rio Paciência da ilha do Maranhão. Bol. Lab. Hidrobiol., 20(1): 31-38.

SILVA JÚNIOR, M.G., CASTRO, A.C.L., SAINTPAUL, U. \& PORTO, H.L.R. 2013. Caracterização da ictiofauna em três canais de maré do estuário do rio paciência, ilha de São Luís, estado do maranhão. Arq. Cienc. Mar., 46(1): 5-21.

SOARES, L.S., SILVA JÚNIOR, M.G., CASTRO, A.C.L. \& SAINT-PAUL, U. 2011. Comunidade de peixes como Indicador de Qualidade Ambiental de alguns canais de maré do estuário do Rio Paciência, São Luís-MA. Bol. Lab. Hidrobiol., 24(1): 1-12.

TAYLOR, W.R. \& MENEZES, N.A. 1978. Ariidae: Sea Catfishes. Pp. 1-37. In: Fischer, W. (ed). FAO species identification sheets fishery purpose. Western Central Atlantic (fishing area 31) Vol. 1. Rome: Food and Agriculture Organisation.

VALENCIENNES, A. 1840. In: Cuvier, G. \& Valenciennes, A. 1840. Histoire naturelle des poissons. Tome quinzième. Suite du livre dix-septième. Siluroïdes. Paris, V. Levrault, Strasbourg, 540 pp. 